\title{
Swedish Lesser White-fronted Geese Anser erythropus in the Baltic States
}

\author{
Svenska fjällgäss i de baltiska staterna
}

\section{HAKON KAMPE-PERSSON}

The Lesser White-fronted Goose Anser erythropus is a globally threatened species (www.iucnredlist. org), listed as Critically Endangered in Sweden (www.artfakta.se). The species' only breeding population in the European Union is found in Sweden, a population that numbered about 45 birds in the spring of 2014 (Niklas Liljebäck in litt.). As the Lesser White-fronted Goose is included in Annex I of the Bird Directive, Sweden is under an obligation to take actions to ensure survival and reproduction of the species in its area of distribution (www.ec.europa.eu).

Lesser White-fronted Geese breeding in Sweden in the 20th century belonged to two different populations: those in northernmost Lapland belonged to the North Fennoscandian population and the others, further south to the Scandinavian population (Kampe-Persson 2009). There were marked differences in migration routes between these populations (Rosenius 1937, Kampe-Persson 2009). After large decreases in numbers only two small breeding populations remained west of Russia, one in northern Norway and one in Sweden.

A reinforcement project was launched in Sweden in 1976 when the Scandinavian population faced the risk of becoming extinct (von Essen 1982). Captive-bred Lesser White-fronted Goose goslings were released with Barnacle Geese Branta leucopsis as foster parents in a traditional breeding area in Swedish Lapland, where the species reportedly had become extinct. However, extensive investigations in literature and archives showed that a rest population still existed in the release area, when the reinforcement project started (Andersson \& Larsson 2006). By the help of the foster parents a migration route to wintering quarters in The Netherlands was established (von Essen 1999).

Due to doubts about the genetic purity of the captive stock no birds were released during the years 2000-2009. Meanwhile, a new captive stock was built up, based on wild-caught birds from Russia (Blomqvist 2014). When releases resumed in 2010, the method used was to release young birds in the neighbourhood of experienced Lesser Whitefronted Geese. The reason to choose this method was to avoid hybridization between released birds and Barnacle Geese. The idea was that the released birds should join experienced Lesser White-front Geese and follow them to wintering quarters in The Netherlands. If that did not work the released birds would probably end up wintering together with White-fronted Geese Anser albifrons somewhere in north-western Europe. In such case, there would be a high probability that several of the males would join the White-fronted Geese when they in spring left for their breeding grounds in Russia.

Before forming pair bonds for the first time many male geese make exploration trips, often taking them to alternative sites for staging, breeding, moulting and/or wintering. Some of these trips result in natal dispersal (see e g Nilsson \& Persson 2001). Other surviving males usually return to their point of origin. For a Lesser White-fronted Goose wintering in one of the established wintering quarters in The Netherlands, the logical alternative to choose when making an exploration trip would be to follow White-fronted Geese when they leave for their Russian breeding grounds. During their prenuptial migration most White-fronted Geese make stop-over in the Baltic States. From there the male can continue to follow the Greater White-fronted Geese, join Lesser White-fronted Geese from the North Fennoscandian population or return to Sweden. The first-mentioned alternative exposes the bird to a higher mortality risk due to hunting.

To be able to adopt the best method for releasing captive-bred Lesser White-fronted Geese in Sweden, it is of importance to get information about individuals following White-fronted Geese during their pre-nuptial migration. As all Lesser Whitefronted Geese released in Sweden are marked with coloured leg-bands, re-sightings could be obtained from the Baltic States, providing the birds make stop-over in those countries. However, are goose flocks staging in the Baltic States checked in such a way that Lesser White-fronted Geese fitted with coloured leg-bands are found and identified?

\section{Monitoring}

The Nemunas River delta in south-western Lithuania is an important staging area in spring, with up 
to $200,000-250,000$ geese at the same time, the vast majority of them White-fronted Geese (Julius Morkūnas in litt.). That Lesser White-fronted Geese from the North Fennoscandian population were staging in this area was discovered on 18 April 2007, when a male fitted with a satellite transmitter landed there (Kaartinen et al. 2009). For that reason, volunteers have checked staging goose flocks in accessible parts of the Nemunas River delta for the occurrence of Lesser Whitefronted Geese since 2011 (Julius Morkūnas in litt.).

In the springs 2011-2014, two, three, three and eight sightings, respectively, of Lesser White-fronted Geese were reported from the Nemunas River delta (www.birdlife.lt). Most of these observations were of single birds but a flock of 15 was seen on 24 April 2012. In 2014, four males from the Swedish project were seen. All four had been released as first calendar-year birds, one in the breeding area at Svaipa in 2012, the other three at the moulting site in Hudiksvall in 2013.

During studies of staging geese in Latvia, the author has checked as many flocks as possible since 2008, especially in the spring of 2013 when a total of 33 staging areas were visited. Based on this field-work the number of staging Lesser Whitefronted Geese in Latvia in the springs 2008-2014 was estimated to range 1-5 individuals (KampePersson 2014). In the springs 2011-2014, the species was observed three times; one adult 18 April 2013 at Lake Zebrus and one adult 24 and 26 April 2014 at Svētes lower reaches.

In Estonia, Lesser White-fronted Geese from the North Fennoscandian population have been monitored every spring since 1999 (Toming 2014). Of 48 observations in the springs 2011-2014, none of them before 19 April, one was of a single bird, seven of two birds and the others of 3-29 birds (www. estbirding.ee, www.piskulka.net). No marked bird of Swedish origin has been re-sighted during monitoring work in Estonia (Toming 2014, Seppo Ekelund pers. comm.). Four re-sightings of Swedishmarked birds were obtained during monitoring of Barnacle Geese in western Estonia however (Leito 1994, Tolvanen et al. 2004). Other individuals passed the Baltic States unnoticed but were later on shot in Russia (Jan-Eric Hägerroth pers. comm.).

\section{Conclusions}

The Lesser White-fronted Goose is hard to spot and count, also by experienced observers today, when occurring in flocks of the White-fronted Goose (for references, see Kampe-Persson 2008). To monitor staging North Fennoscandian Lesser White-fronted Geese in Estonia is feasible (Toming 2014) but to find all Lesser White-fronted Geese staging in the Baltic States is unrealistic. Occurrence pattern in Estonia of North Fennoscandian birds can be used as a guideline to determine the origin of unmarked individuals and birds where the legs were not seen. Single Lesser White-fronted Geese found in Lithuania and Latvia, especially when seen before 19 April, most likely originate from the Scandinavian population. Thus, the minimum number of Scandinavian birds observed in the Baltic States in the years 2011-2014 was one, two, four and eight individuals, respectively. These numbers might give a somewhat skewed picture of the true occurrence in the Baltic States, however, due to the fact that only a few of the more than 100 staging areas for Whitefronted Goose in the Baltic States were checked for the occurrence of Lesser White-fronted Geese.

In the Nemunas River delta, the White-fronted Geese start to arrive in mid March, numbers peak in the first half of April and the last birds leave during the second week of May (Julius Morkūnas in litt.). With the exception of a later departure among the last birds the pattern is the same in Latvia as in Lithuania (Kampe-Persson 2014). So, it is plausible to assume that the White-fronted Geese staging in these two countries mostly are made up of different groups. It is much harder to look for Lesser White-fronted Geese in Latvia than in Lithuania however, as the White-fronted Geese are staging all over the country. Despite observational difficulties it would be desirable if at least the main flocks of White-fronted Geese in Latvia could be checked for the occurrence of Lesser White-fronted Geese. If such monitoring could be realized in Latvia, at the same time as the monitoring in Lithuania was maintained on at least the same level as earlier, the basic prerequisites of obtaining re-sightings of Swedish-marked Lesser White-fronted Geese staging in the Baltic States would be fulfilled.

\section{References}

Andersson, Å. \& Holmqvist, N. 2010. The Swedish population of Lesser White-fronted Goose Anser erythropus - supplemented or re-introduced? Ornis Svecica 20: 202-206.

Andersson, Å. \& Larsson, T. 2006. Reintroduction of Lesser White-fronted Goose Anser erythropus in Swedish Lapland. Pp. 635-636 in Waterbirds around the world (Boere, G., Galbraith, C. \& Stroud, D., eds.). The Stationary Office, Edinburgh.

Blomqvist, L. 2014. Lesser white-fronted geese. Nordens Ark Annual Report 2013: 16-17. Nordens Ark Foundation, Hunnebostrand. 
Essen, L. von 1982. Ett försök att återinplantera fjällgåsen i den skandinaviska fjällkedjan. Pp. 109-110 in De svenska gässen (Svensson, S., ed.). Vår Fågelvärld, Supplement No. 9. Sveriges Ornitologiska Förening, Stockholm.

Essen, L. von. 1999. The Swedish reintroduction project of Lesser White-fronted Geese. Pp. 53-55 in Fennoscandian Lesser White-fronted Goose conservation project. Annual report 1998 (Tolvanen, P., Øien, I.J. \& Ruokolainen, K., eds.). WWF Finland Report 10 \& Norwegian Ornithological Society, NOF Rapportserie Report No. 1-1999, Helsinki \& Klæbu.

Kaartinen, R., Castreén, K. \& Tolvanen, P. 2009. Spring stage site of Fennoscandian Lesser White-fronted Geese revealed in the Nemunas delta, Lithuania. Pp. 16-17 in Conservation of Lesser White-fronted Goose on the European migration route. Final report of the EU LIFE-Nature project 2005-2009 (Tolvanen, P., Øien, I.J. \& Ruokolainen, K., eds.). WWF Finland Report 27 \& Norwegian Ornithological Society, NOF Rapportserie Report No. 1-2009, Helsinki \& Trondheim.

Kampe-Persson, H. 2008. Historical occurrence of the Lesser White-fronted Goose Anser erythropus in the Atlantic flyway. Ornis Svecica 18: 69-81.

Kampe-Persson, H. 2009. Vart flyttade de svenska fjällgässen? Fåglar $i$ Västerbotten 34: 29-43.

Kampe-Persson, H. 2014. Where, when and how many geese stage in Latvia? Goose Bulletin 19: 11-13.

Leito, A. 1994. P. 46 in Birds of Estonia. (Leibak, E., Lilleleht, V. \& Veromann, H., eds.). Estonian Academy Publishers, Tallinn.

Nilsson, L. \& Persson, H. 2001. Natal and breeding dispersal in the Baltic Greylag Goose Anser anser. Wildfowl 52: 21-30.

Rosenius, P. 1937. Sveriges fåglar och fågelbon. Vol. 4. Gleerups, Lund.

Tolvanen, P., Toming, M. \& Pynnönen, J. 2004. Monitoring of Lesser White-fronted Geese in western Estonia in 2001-2003. Pp. 9-13 in Fennoscandian Lesser Whitefronted Goose conservation project. Report 2001-2003 (Aarvak, T. \& Timonen, S., eds.). WWF Finland Report 20 \& Norwegian Ornithological Society, NOF Rapportserie Report No 1-2004, Helsinki \& Trondheim.

Toming, M. 2014. Monitoring of Lesser White-fronted Geese in Estonia - Finnish-Estonian united efforts. P. 15 in WWF:n kiljuhanhityöryhmä 30 vuotta. 20 pp. WWF, Helsinki.

\section{Sammanfattning}

När man efter ett uppehåll på tio år återigen började sätta ut fjällgäss i Sverige år 2010 gjordes detta utan fosterföräldrar. Denna metod valdes för att undvika att hanar skulle bilda par med vitkindad gås. Förhoppningen var att de utsläppta gässen skulle slå följe med äldre erfarna fjällgäss och följa dem till övervintringskvarteren i Nederländerna. Om detta misslyckades fanns risk att de utsläppta gässen skulle tillbringa vintern någon annanstans samt att en del hanar skulle följa med bläsgäss, då dessa lämnade vinterkvartern för att flytta till sina häckningsområden i Ryssland. För att förbättra utsläppsmetoderna är det av stort intresse att veta vilka hanar som följer med bläsgäss. Ifall rastande bläsgåsflockar noggrannt kontrollerades med avseende på ingående fjällgäss skulle sådana uppgifter kunna erhållas från Baltikum.

I Nemunasdeltat i Litauen, där antalet samtidigt rastande gäss, framförallt bläsgäss, om våren uppgår till 200.000-250.000, har frivilliga genomspanat flockarna efter fjällgäss årligen sedan 2011. 2014 hittades fyra märkta fjällgåshanar utsläppta som 1K-fåglar i Sverige, en i häckningsområdet 2012 och tre på ruggningslokalen i Hudiksvall 2013. Baserat på eget fältarbete har antalet rastande fjällgäss i Lettland under vårarna 2008-2014 uppskattats till 1-5 individer. I Estland har rastande norska fjällgäss studerats sedan 1999 utan att någon svenskmärkt fågel setts. Av totalt 48 observationer vårarna 2011-2014, ingen före den 19 april, var det endast en som gällde en ensam fågel.

Om fjällgäss sedda ensamma i Litauen och Lettland inte var norska, utgjorde antalet observerade fjällgäss av troligt svenskt ursprung 1, 2, 4 respektve 8 under vårarna 2011-2014. Detta är dock minimiantal, ty det var endast bläsgåsflockar på ett fåtal av de mer än 100 rastområden som finns i dessa båda länder som genomspanades. Då bläsgässen som rastar i Litauen och Lettland till största delen utgörs av olika fåglar, skulle det vara önskvärt om även bläsgåsflockarna på de viktigaste rastlokalerna i Lettland årligen kunde genomspanas efter fjällgäss. Om sådana fältkontroller kunde genomföras i Lettland, samtidigt som fältarbetet bibehölls på åtminstone samma nivå som tidigare i Litauen, skulle förutsättningarna för att erhålla observationer av rastande svenskmärkta fjällgäss i Baltikum vara uppfyllda.

\section{Hakon Kampe-Persson}

Pulmañi, Glüdas pagasts, Jelgavas novads, LV3040, Latvia

kampepersson@hotmail.com 